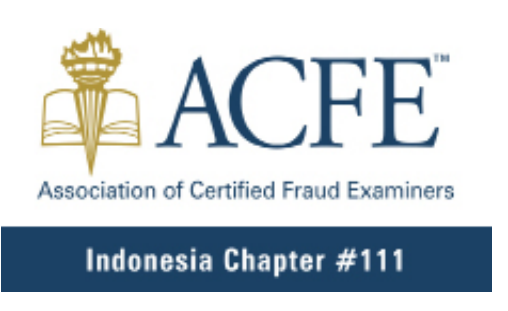

Asia Pacific Fraud Journal E-ISSN: 2502-695X, ISSN: 2502-8731

Volume 6, Nomor 1 (January-June) 2021

Asia Pacific Fraud Journal now has been accredited "SINTA 3" by Ministry of Research and Technology of The Republic of Indonesia (No SK. 85/M/KPT/2020).

Availaeble online at: http://apfjournal.or.id/index.php/apf

\title{
The Association Between Fraud Hexagon and Government's Fraudulent Financial Report
}

\author{
${ }^{\square}$ Ryan Aviantara \\ Magister Accounting, Trisakti University Jakarta, Indonesia
}

\section{ARTICLE INFORMATION}

\section{Article History:}

Received August 1, 2020

Revised November 6, 2020

Accepted 21 June 2021

DOI:

10.21532/apfjournal.v6i1.192

\begin{abstract}
ABTRACT
This paper aims to analyze the determinant factors of Vousinas S.C.C.O.R.E model asrenowned as Fraud Hexagon against the Fraudulent Financial Report (FFR) which measured by Dechow F-Score. The population in this study is government company from the consolidated audited report of Ministry if SOE's (State Owned Enterprises) along 5 years with purposive sampling technique according to the largest assets. By using the logistic regression statistic method, the empirical evidence of this study shows that S.C.C.O.R.E model has ability to affect the FFR. However this paper evolve breakthrough variables through E-Procurement, Change in Audit Committee, Whistleblowing System, CEO Education and CEO Military which can be explored further on the next research.
\end{abstract}

Keyword: Fraud Hexagon, Vousinas, Fraudulent Financial Report, F-Score, Dechow, BUMN.

\section{INTRODUCTION}

Association of Certified Fraud Examiners (ACFE), on April 2020 released the "Report to the Nations" represent the latest series of reports which provided a global analysis of the costs and effects of occupational fraud. The report highlights the tremendous impact of occupational fraud in the organizations throughout the world with covers 2,504 cases from 125 countries and resulted in losses of $\$ 3.6$ billion, median losses per case were $\$ 125,000$, while the average loss per case was $\$ 1,509,000$. This report consistent with prior years findings that organizations lose $5 \%$ of revenue to fraud each year. There were sixty-four percent of companies victimized by fraud last year had whistleblower hotlines, and thosecompanies experienced smaller losses (median losses of $\$ 100,000$ versus $\$ 198,000$ ) that were caught earlier (12 months versus 18 months). Twenty-eight percent of whistleblowers first reported their

${ }^{\triangle}$ Corresponding author: Email: ryan.aviantara@gmail.com

The 2nd Runner Up National Call for Paper ACFE Indonesia Chapter 2020 allegations to their direct supervisor, and another 11 percent went to a more senior executive. Only 14 percent went to a fraud investigations team, and 12 percent went to internal audit. Related to the perpetrators, $51 \%$ of frauds were committed by two or more fraudsters working in collusion, the median loss was $\$ 445,000$ five times from the single perpetrator which is $\$ 90,000$. Losses tended to increase with multiple perpetrators particularly when three or more individuals conspired to commit fraud. One reason collusive frauds might be more costly is that multiple fraudsters working together might be better able to undermine the systems of separated duties and independent verification that are at the heart of many anti-fraud controls (ACFE, 2020).

In the meantime Vousinas (2019), introduced The Advancing of SCORE model (S.C.C.O.R.E) or called Fraud Hexagon with collusion as the complement

Association of Certified Fraud Examiners (ACFE) Indonesia Chapter Page. 26-42 
factor of Cressey' Fraud Triangle. This hexagon theory considered novelty as the fraud research up to pentagon analysis. As far research for, there is a paper from Hafizi that he presented at the XXII National Accounting Symposium in Papua on October 2019. He proxied the collusion factor with the audit fee, as this lead to the complexity of conflict of interest to provide a clean report without any exception in order to maintain the client. Auditors are become reluctant to declare findings to management, even revealed that they collude with clients to cover fraud as Enron Corp and Arthur Andersen did in manipulating the financial statements with large audit fees, thus in 2001 Indonesia Corruption Watch (ICW) ever asked the police to investigate 9 accounting firms which suspected of having collusion with 36 bank between 1995-1997, and within 2005-2017 there were at least 6 collusion cases through selling the unqualified (WTP) opinions, involving 23 auditors from Audit Board Indonesia (BPK) (Hikmawati, 2017).In addition, this concise paper develop some new variables based on the latest ACFE report, including the whistleblowing system, the procurement system, the educational background, and the military connection which being the national issues. Financial crime might be never stop, but there is always a wayto fight.

\section{LITERATURE REVIEW AND HYPO- THESIS}

Agency Theory

Theory of the relationship between principal and agent has been warmly discussed by academics-practitioners in the field of social sciences and economics since the 1970s. Ross and Mitnick claim that they are the first who issue "The Theory of Agency". However, the most frequently cited reference regarding the "Agency Theory" is derived from the statement of Jensen and Meckling which define as a contract in which one person or more (as the principal) bind to another person (as the agent) to carry out activities on behalf of the principal, and the principal gives the agent some authorities to take decision. In the agency relationship, each of the parties is likely to maximize its own utility and the agent does not always act in accordance with the wishes of the principal. Therefore, the principal can limit the agency problem/conflict of interest by spending agency cost. Agency problem occurs at any levels of organization, any levels of management, universities, corporations, various forms of cooperation, and also government. The problem of information asymmetry is the basis of any problem of conflict of interest and consequently increases the risk of fraud. Managers have an obligation to convey information in accordance with the actual condition of the company to shareholders, but sometimes the information submitted is not in accordance with the actual situation. So, fraud can occur because it is armed with more information about the company. Information asymmetry is a condition in which agents have more information about a company than principals so managers tend to try to manipulate reported company performance (Jensen and Meckling, 1976).

\section{Fraud Hexagon}

Conflicts of interest between the principal and the agent lead to the attitude of distrust, because agent will act in the interests of personal interests, not maximize the interests of the principal. This condition provides a great opportunity for agents to commit fraud. Fraud occurs because of human nature, selfishness, have limited thinking power regarding future perceptions (bounded rationality), and always risk averse. Self interest regard to pressureness, capabilities, and arrogance factors, on the other side risk averse regard to opportunities and rationalizations factors. The fundamental theory that becomes the basis of fraud study is white collar crime triangle or fraud triangle which was first introduced by Cressey (1953) by interviewing 113 people who have committed embezzlement in companies, or called "trust violators". 
The fraud standards existing in SAS No. 99 are based on the fraud theory initiated by Cressey. This theory being enhance to adapt to the current developments in the field and the ever growing fraud incidents, both in frequency and severity. And the most recent model introduced by Georgios (2019), identifies a major element "Ego" which plays a crucial role in compelling people to commit fraud, and concludes in the formation of the S.C.O.R.E. model (Stimulus, Capability, Collusion, Opportunity, Rationalization, Ego) this graphically captured in the fraud pentagon, then he goes further by adding the factor "Collusion" to better apply in cases of white-collar crimes, as this is being the key factor in committing fraud which caused median losses became far greater when fraudsters collude.

Figure 1. The Fraud Hexagon

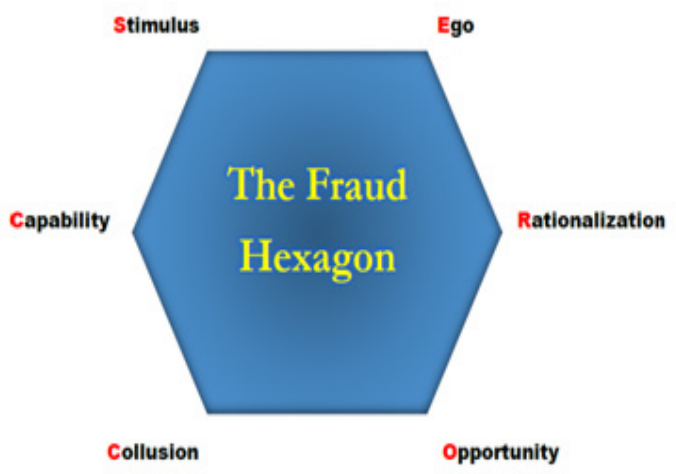

\section{Fraudulent Financial Report}

Fraudulent Financial Report (FFR) is the deliberate misstatement or omission of company financial statement data with the intent of misleading the reader to believe the company is in a better financial position than the truth is. FFR usually involves overstating assets, revenues, and profits and understating liabilities, expenses, and losses. However, the overall objective of the manipulation may sometimes require the opposite action, e.g., concealing higher-than-expected revenues or profits in a good year to help the subsequent year that is expected to be tougher. These instances tend to be much larger in terms of dollar amounts and much more complex in execution in comparison with those of corruption and asset misappropriation. Generally, with asset misappropriation and corruption, the fraudster prefers that the amounts be smaller so as not to raise any eyebrows, whereas with financial statement fraud the fraudster would need to grossly exaggerate the numbers to convince the reader that the company is financially sound and prosperous (Klein \& Fitzgerald, 2018). Accounting manipulation, a type of fraud whereby executives of a firm distort or change financial statement information to portray a falsely positive image of their company, has proven to be particularly damaging to our capital markets system (Skousen \& Twedt, 2009). Despite the reports of the ACFE, most frauds are not detected in time because they are normally hidden from the eyes of the public or even the auditors. The high losses due to fraud reported by different organizations also confirmed failure in detection. Therefore, an effective tool is required to identify the signals of fraud.

I used Dechow f-score to measure the magnitude of FFR. The f-score is claimed to be more comprehensive than m-score which introduced earlier by Beneish (1999), since the f-score is based on an examination of all Accounting and Auditing Enforcement Releases (AAERs) issued by the SEC between 1982 and 2005 (23 years), while the Beneish study was based only on AAERs issued between 1982 and 1992 (10 years). And studied by Aghghaleh et al. (2016), who examined Malaysian listed companies from 2001 to 2014, the results reveal that Dechow F-score model outperforms the Beneish M-score model in the sensitivity of predicting fraud cases with $73.17 \%$ compared to 69.51\%. However, Dechow et al. (2011), found that their first model offers the "bulk of the power" in predicting material accounting misstatements. Score higher than 1.0 indicates higher probabilities of misstatement. The model computed mathematically as follow:

- $\mathrm{F}=$ Probability Value / Unconditional Probabilty 
Unconditional Probabilty $=0.0037$

- Probabilty Value $=\mathrm{e}^{\text {(Predicted Value })} /(1+$ $\mathrm{e}^{\text {(Predicted Value) })}$ $\mathrm{e}=2.71828183$

- Predicted Value $=-7.893+$ $0.790 *$ RSST $+2.518^{*} \triangle \mathrm{REC}+$ $1.191 * \triangle \mathrm{INV}+1.979 *$ SOFTASSETS + $0.171^{*} \Delta$ CASHSALES $-0.932^{*} \Delta$ ROA + $1.029 *$ ISSUE

The detail computation from each variable of predicted value describein appendices.

\section{Hyphothesis Development}

Skousen et al. (2009), indicates when a company is growing under the industry average, management might manipulate their financial statements to improve the company performance. The company's financial stability can be seen from the total assets owned, a large number of company's assets are considered to provide the maximum returns for the investors. The greater ratio of asset growth, the greater probability of fraud risk as thisproven by Tessa \& Harto (2016), Siddiq et al. (2017), Aprilia (2017), Septriani \& Handayani (2018), that financial stability has a significant effect to FFR. Hence the hypothesis proposed. ---> H1: Financial Stability affect to FFR.

Robbins \& Judge (2015), defines capability as a skill (ability) to perform various tasks in a job. The fraud concept consider 'capability' in determine the profile of fraudsters, these individuals must have ability to find the loopholes and create opportunities for own advantages. Changes in directors are often filled with political content and the interests of particular parties which trigger the conflict of interest (Rahardjo \& Sihombing, 2014). However this bring out a stress period, aninstability condition of command and control to the company's activities, management who has capability to design strategies and determine the right time to commit fraud utilised this instability to reap benefits (Wolfe \& Hermanson, 2004). Marurung \& Hardika (2015), Siddiq et al. (2017), Sasongko \& Wijayantika (2019), proved the significance between the change of directors to FFR. Hence the hypothesis proposed. ---> H2: Director Change affect to FFR.

Audit Firms who receive high fees tend to face the complexity of conflict of interest, pertaining deliver clean reports (unqualified opinion), and tendency to maintain clients from moving to others by creating good relations (Bamber, 2001). Auditors are became reluctant to carry findings, even in some case revealed that auditors collude with clients to cover fraud, we are know the chronicle between Enron and Arthur Andersen when manipulated financial reports with large audit fees, in 2001 Indonesia Corruption Watch ever asked the police to investigate 9 accounting firms which suspected of having collusion with 36 bank between 1995-1997, and within 2005-2017 there were at least 6 collusion cases through selling the unqualified opinions, involving 23 auditors from Audit Board Indonesia (Hikmawati, 2017). Since the collusion factor from Vousinas (2019), is considered new in fraud terminology, hence not many researcher explore this proxy, only Hafizi (2019), tested the significance relationship between the audit fee and FFR through his paper. Therefore this paper is aim to strengthen the theory with the hypothesis proposed. ---> H3: Audit Fee affect to FFR.

Among the most collusion practices in the government sector is through a procurement or tender mechanism. Tender collusion occurs when business actors, conspire to increase prices or reduce the quality of goods or services. This collude become more destructive when undertaking public procurement. The conspiracy take resources from buyers and tax payers, reduces public trust and reduces benefits from competitive market (OECD, 2009). In respond to the that fraud model, a system designed as E-Procurement/ETendering/E-Purchasing, likewise the price is transparent because it published through the electronic catalog (Wibowo, 2015). Several studies from Jasin et al. (2007), Djojosoekarto (2008), Haryati et 
al. (2011), confirmed that E-Procurement or E-Tendering was more preventing the fraud (collusion). Hence the hypothesis proposed. ---> H4: E-Procurement affect to FFR.

Many researchers are examined the internal auditor change related to its knowledge and the understanding of business environment and internal control structure,but still rare study ofchange in audit committee. The characteristics of audit committee studies are among size, number of meetings, independency, and expertise as performed by Abbott et al. (2000), Davidson et al. (2005), Lisa \& Robinson (2009), Rahmat et al. (2009), Lee \& Fargher (2012), Kamarudin \& Ismail (2014), Rahmawati \& Marsono (2014), Cahyo \& Sulhani (2017). However Klein (2002), found that firms changing their boards and or audit committees from majority-independent to minorityindependent significantly larger increases in abnormal accruals vis-a-vis their counterparts. These findings support the hypothesis that earnings management is negatively related to independent boards and audit committees. Loebbecke et al. (1989), found that $36 \%$ of cases of fraud occurred within the first two years of the auditor's tenure. And Krishnan (2005), found sample companies who changing the audit commitee were not disclosed internal control problems. Indeed the committee audit hascrucial role in oversees the firm's financial reporting process including review the corporation's financial reports, audit process, and internal accounting controls (Klein, 2002). Therefore the hypothesis would be. ---> H5: Change in Audit Committe affect to FFR.

Whistleblowing system (WBS) is designed as an effort to prevent fraud. This system encourages the company to provides employees protection of fraud report scheme. WBS is considered as valuable instrument in corporate governance strategies, help to maintain workplace safety, as well as company profits and reputation (Susmanschi, 2012). Companies who own big assets are urgently need of complaints channels such as hotlines to detect fraud rather than performing direct control which will be less effective. According to Lee \& Fargher (2012), that WBS procedures are specifically found to be more likely to revealed by large companies. Naomi (2015), conducted an exploratory study of state companies who implemented whistleblowing system, the results shown that the application of WBS in Telkom and Pertamina run quite well due to decrease in the level of fraud from 2010 to 2013. Hence the hypothesis proposed. ---> H6: Whistleblowing Systemaffect to FFR.

Majority ownership has power to control management, a larger share percentage might affect the process of preparing financial statements that rule out the standards with discretional accrual from the controlling parties. Aviantara (2019), obtained empirical evidence from the effect of government ownership to FFR, he argue that the major government ownership become a rationalization for the management to commit fraud, while the tendency and the circumstance are considered high in public sector as report by Survey Fraud Indonesia (2017). Hence the hypothesis proposed. ---> H7: Government Ownershipaffect to FFR.

Educational background is required to provide superior performance in large and complex business (Juliana \& Erlim, 2017). This affects the ability of CEO in 3 ways: (1) Education has potential to contribute in knowledge, perspectives, and the ability to understand the abstract technical and technical concepts. (2) Higher education being a picture of CEO intelligence and capability in facingthe challenge intellectual activity. (3) Connections that obtained in the college can professionally used in future workplaces (Bhagat et al., 2010). While CEO with higher educational background can process information quickly and able to accept significant transformation in a company (Bantel and Jackson, 1989). However the level of education captured from how high the achievement of a CEO as King et al. (2016), 
explained that the level of undergraduate education provides basic training for the CEO to help develop the skills he has, the postgraduate level represents a level of management and knowledge gained from the master's program, and the $\mathrm{PhD}$ education shows the level of technical expertise obtained from a doctorate. ACFE (2020), also reported that the perpetrators from postgraduate $(15 \%)$ degree lower than the lower degree. Therefore a higher level of education expect a CEO to be more aware and wise to the anti-fraud behavior, hence the hypothesis is formulated as follows. ---> H8: CEO Educationaffect to FFR.

It is said that the existence of military in executive position has existed since 1960s (Muradi, 2007). During that period the military men entered to private sector through their control and power of center political-bureaucratic, those army men did not only engage in defense territory, but also expanded into the political-economic sphere. Crouch (1978), started with opinion that military connections can be defined as a substitute for the quality of corporate governance in order to reduce interest costs in developing countries, the result is that military-connected companies will have lower interest rates than non militarily connected, his hypothesis en-dorsed by Lennox et al. (2011), Kim \& Zhang (2016), Harymawan (2018). Then Kamelia (2018), concluded that the background military of a CEO impact significantly to the selection of revaluation methods used to facilitate the companies in obtaining additional loan funds and attract the investors. But the question is whether the CEO maneuver matching the rules of accounting? Does CEO maneuver free from fraudulent

\section{Figure 2. The Conceptual Framework}

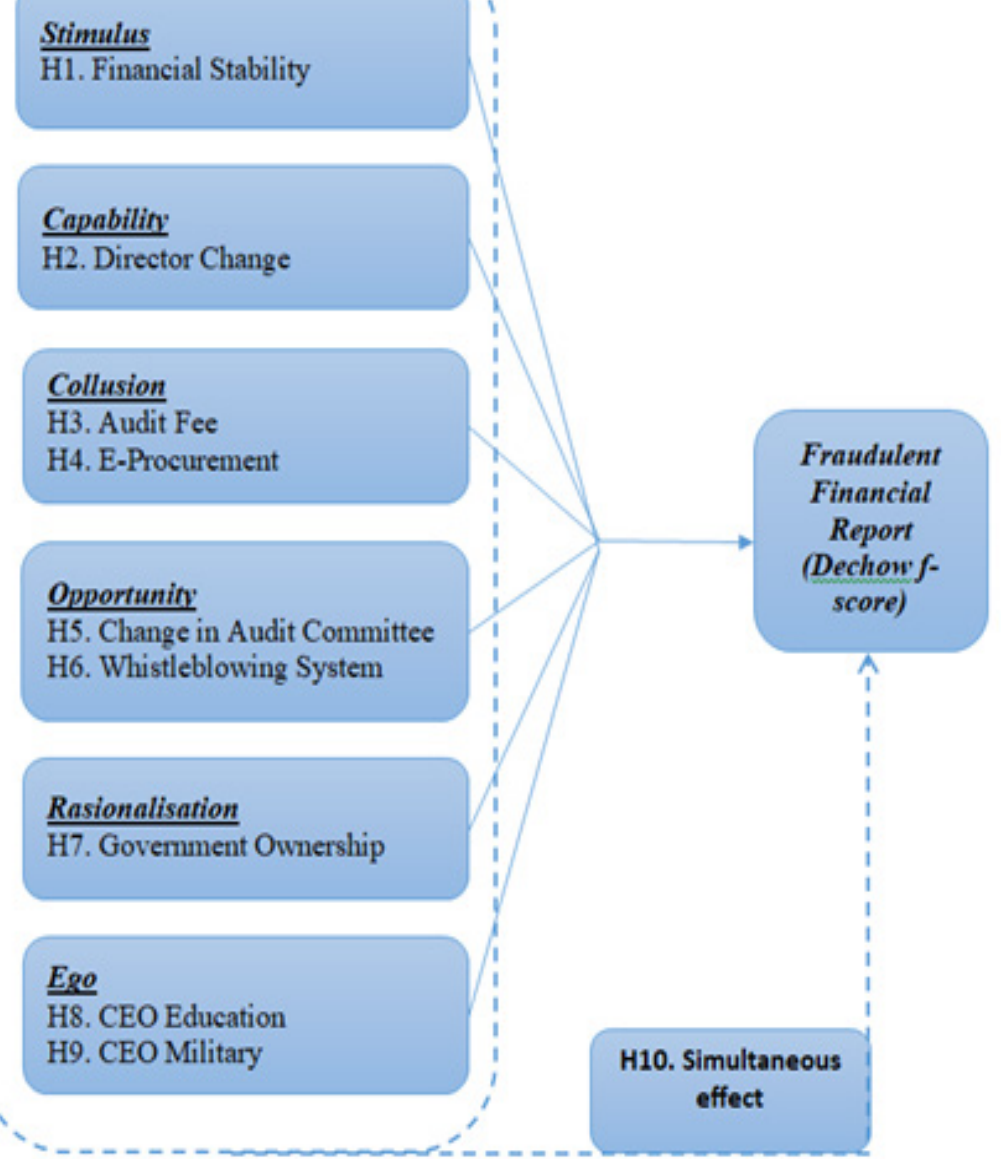


financial reports? Until now public still finding the fact of connection between military background in certain fraud cases, this emerge negative perception that the military existence is a weaponto secure the owner's business by paving the way in licensing and security matters. Hence the hypothesis proposed. ---> H9: CEO Militaryaffect to FFR.

Some researchers taken a simultaneous test of fraud pentagon factors against the fraudulent financial reports. Aprilia (2017), Agustina \& Pratomo (2019), obtained empirical evidence that all factors they indentified in Fraud Pentagon simultaneously can affect the FFR. This paper going advance by testing the Fraud Hexagon factors as Financial Stability, Director Change, Audit Fee, E-Procurement, Change in Audit Committee, Whistleblowing System, Government Ownership, CEO Education, and CEO Military. Hence the hypothesis formed. ---> H10: Fraud Hexagon (S.C.C.O.R.E model) affect to FFR.

\section{METHODS}

This paper obtained 5 years observation (2014-2018) from the Indonesian state company. I designed criteria based on the value of assets according to the consolidated 2018 SOE Ministry's audited reports (see appendices). When I sorted out the list from the highest, there was a significant gap from the 29th (IDR 30.1 trillion) to the 30th (IDR 18.2 trillion), thus the purposive sampling was taken from the assets beyond IDR 30 trillion. For the statistic analysis I used regression logistic method due to the FFR score reflects the indication, while Ghozali (2016), explained the purpose of the logistic regression analysis is to determine whether there is a possibility that the dependent variable can be predicted with the independent variable. And expressed in below (Table 1).

The equation regression model in this study as follow: $\ln =\mathrm{FFR} /(1-\mathrm{FFR})=$ $\alpha+\beta 1$ AGROW $+\beta 2$ BODC $+\beta 3$ AUDF $+\beta 4 \mathrm{EPRO}+\beta 5 \mathrm{CHGAC}+\beta 6 \mathrm{WBS}+\beta 7$ GOVHSIP $+\beta 8$ CEOEDU $+\beta 9$ CEOEMIL $+\varepsilon$

Table 1. The Variables Measurement

\begin{tabular}{|c|c|c|c|}
\hline Var & Factor & Model & Measurement \\
\hline $\mathrm{Y}$ & $\begin{array}{l}\text { Fraudulent } \\
\text { Financial Repot }\end{array}$ & Dechow F-Score & Dummy: 1 if score $>1,0$ if score $<1$ \\
\hline $\mathrm{X} 1$ & Stimulus & $\begin{array}{l}\text { Financial Stability } \\
\text { (AGROW) }\end{array}$ & $\begin{array}{l}(\text { Total asset }(n)-\text { Total asset }(n-1)) / \\
(\text { Total asset }(n-1))\end{array}$ \\
\hline$X 2$ & Capability & Director Change (BODC) & Number of directors replacement \\
\hline X3 & Collusion & Audit Fee (AUDF) & Logarithm natural (Ln) \\
\hline $\mathrm{X} 4$ & Collusion & E-Procurement (EPRO) & $\begin{array}{l}\text { Dummy: } 1 \text { if company has } \\
\text { e-procurement portal, } 0 \text { otherwise }\end{array}$ \\
\hline X5 & Opportunity & $\begin{array}{l}\text { Change in Audit } \\
\text { Committee(CHGAC) }\end{array}$ & $\begin{array}{l}\text { Number of audit committee } \\
\text { replacement }\end{array}$ \\
\hline X6 & Opportunity & $\begin{array}{l}\text { Whistleblowing System } \\
\text { (WBS) }\end{array}$ & $\begin{array}{l}\text { Dummy: } 1 \text { if company apply } \\
\text { whistleblowing system, } 0 \text { otherwise }\end{array}$ \\
\hline $\mathrm{X} 7$ & Rationalization & $\begin{array}{l}\text { Government Ownership } \\
\text { (GOVSHIP) }\end{array}$ & Percentage of government ownership \\
\hline $\mathrm{X} 8$ & Ego & $\begin{array}{l}\text { CEO Education } \\
\text { (CEOEDU) }\end{array}$ & $\begin{array}{l}\text { Dummy: } 1 \text { if CEO as Phd / doctoral, } 0 \\
\text { otherwise }\end{array}$ \\
\hline X9 & Ego & CEO Military (CEOMIL) & $\begin{array}{l}\text { Dummy: } 1 \text { if CEO has military } \\
\text { background, } 0 \text { otherwise }\end{array}$ \\
\hline
\end{tabular}

Source: Data Processing 
Asia Pacific Fraud Journal, 6(1) January-June 2021: 26-42 | 33

\section{RESULT AND DISCUSSION}

The initial observation was 29 state companies throughout 5 years, 3 companies did not publish its financial report (ASABRI 2018, JIWASRAYA 2017-2018), and 16 companies were eliminiated due to high residual deviance, hence the final sample taken was 126.

\section{Descriptive Statistic}

I categorized the companies into 6 main industries according to the IDX grouping where the (1) Agriculture; included Plantation. (2) Chemical; included Cement, Fertilizer, Metal. (3) Finance; included Banking, Insurance, Financing. (4) Infrastructure; included Energy, Telecomunication, Transportation. (5) Mining; included Mineral, Petroleum. (6) Property; included Construction. The first is FFR score as depicted Figure 3 and Figure 4.

Figure 3. FFR Score

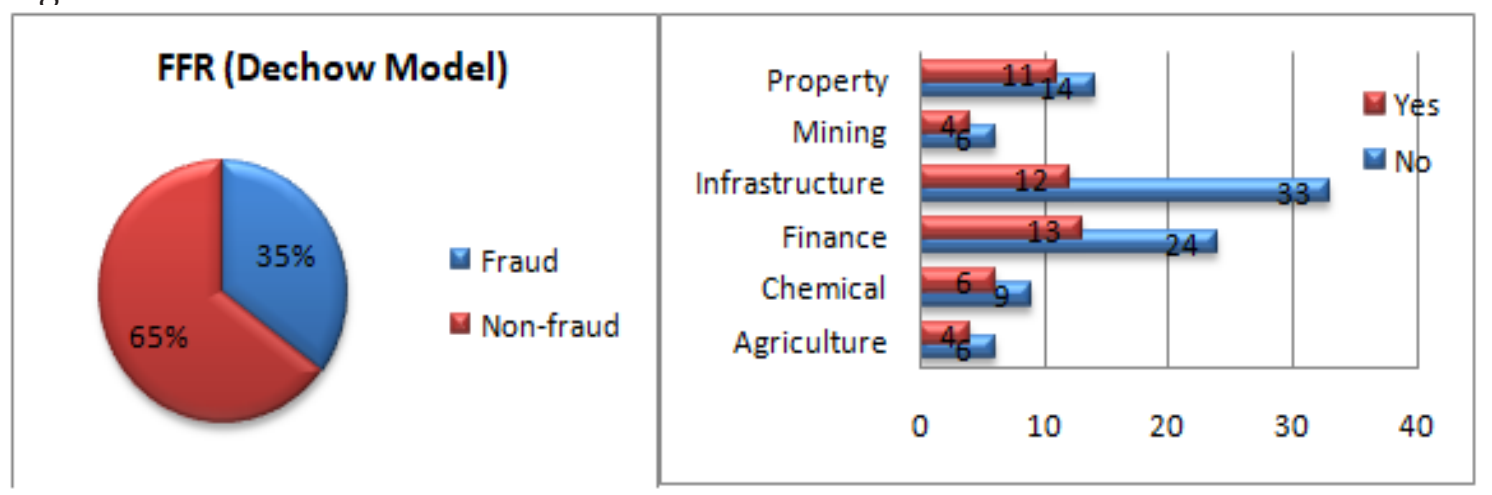

Source: Data Processing

Table 2. Independent Variables

\begin{tabular}{|c|c|c|c|c|c|c|}
\hline No & Variable & $\mathrm{N}$ & Min & Max & Mean & Std. Deviation \\
\hline 1 & AGROW & 126 & $-0,21$ & 2,54 & 0,26 & 0,35 \\
\hline 2 & BODC & 126 & 0 & 8 & 1,91 & 2,02 \\
\hline 3 & AUDF & 126 & 19,69 & 24,50 & 21,67 & 1,06 \\
\hline 4 & CHGAC & 126 & 0 & 5 & 0,96 & 1,09 \\
\hline \multirow[t]{2}{*}{5} & GOVHIP & 126 & 0,51 & 1 & 0,81 & 0,20 \\
\hline & & Category & Frequency & Percent & Valid \% & Cumulative \% \\
\hline \multirow[t]{3}{*}{6} & EPRO & Non E-Pro & 51 & 40,5 & 40,5 & 40,5 \\
\hline & & E-Procurement & 75 & 59,5 & 59,5 & 100 \\
\hline & & Total & 126 & 100 & 100 & \\
\hline \multirow[t]{3}{*}{7} & WBS & Non-WBS & 4 & 3,2 & 3,2 & 3,2 \\
\hline & & Whistleblowing & 122 & 96,8 & 96,8 & 100 \\
\hline & & Total & 126 & 100 & 100 & \\
\hline \multirow[t]{3}{*}{8} & CEOEDU & Non-Phd & 114 & 90,5 & 90,5 & 90,5 \\
\hline & & Phd & 12 & 9,5 & 9,5 & 100 \\
\hline & & Total & 126 & 100 & 100 & \\
\hline \multirow[t]{3}{*}{9} & CEOMIL & Non-Military & 118 & 93,7 & 93,7 & 93,7 \\
\hline & & Ex-Military & 8 & 6,3 & 6,3 & 100 \\
\hline & & Total & 126 & 100 & 100 & \\
\hline
\end{tabular}

Source: Data Processing 
The state companies who have fraud indication is $35 \%$ with the redflag sectors are Finance, Infrastructure, and Property. This figure should be watched by all stakeholders to reduce in the future. Next is Table 2, that defined all independent variables.

The lowest asset growth $-0,21$ was from BULOG in 2014, while the highest 2,54 was from INALUM in 2017 when consolidated the BIG 4 mining; ANTAM, TIMAH, PTBA, FREEPORT, and average growth along 5 years was $26 \%$. The most directors change was 8 personel from GIAA and PERTAMINA in 2018, while the average was 1,91. The lowest audit fee 19,69 was from ASABRI in 2014 to Heliantono \& Partners (Parker Randall), while the highest 24,50 was from TELKOM in 2017 to Purwantono, Sungkoro \& Surja (EY), the average is Ln 21,7 or \pm IDR 2.5 billion. The most change in audit committee was 5 personel from BMRI in 2014 and WIKA 2018, while the average was 0,96. There are 16 companies who $100 \%$ owned by the government while the rest is major ownership above 51\%. E-Procurement; $40,5 \%$ state companies haven't applied where most came from Property and Finance. Whistleblowing system; 3,2\% state companies haven't applied in 2014. CEO Education; 9,5\% CEO from observed companies as a Phd or doctoral degree where the dominant in Infrastructure. CEO Military; 6,3\% CEO from observed companies have military background where the dominant in ASABRI.

\section{Overall Model Fit Test}

The overall model fit test shows by comparing the value of -2Log Likelihood at the beginning (block number $=0$ ) with the value of $-2 \log$ Likelihood at block number $=1$. Decrease in Log Likelihood (before compare to after) shows a better regression model. Table 3 , shows a decrement from 152,558 to 89,678 , hence the logistic regression model in this study overall is feasible to use.

\section{Table 3. Iteration History}

\begin{tabular}{cc}
\hline $\begin{array}{c}\text { Iteration Block } \\
\text { Number }\end{array}$ & $\begin{array}{c}-2 \text { Log } \\
\text { likelihood }\end{array}$ \\
\hline 0 & 152,558 \\
1 & 89,678 \\
\hline
\end{tabular}

Source: Data Processing

\section{Gooddess of Fit Test}

Goodness of fit is demonstrated by using the Hosmer and Lemeshow test with $\mathrm{HO}$ represent goodness of fit and $\mathrm{H} 1$ represent the unfit model. Table 4 , shows significancy $>0,05$ means accepting the $\mathrm{H} 0$, hence the model in this study is able to explain the data, and there is no difference between the model and its observational value. This also indicate that the logistic regression equation in this study can be used to explain the relationship between the independent variable and the dependent variable.

Tabel 5. Classification Table

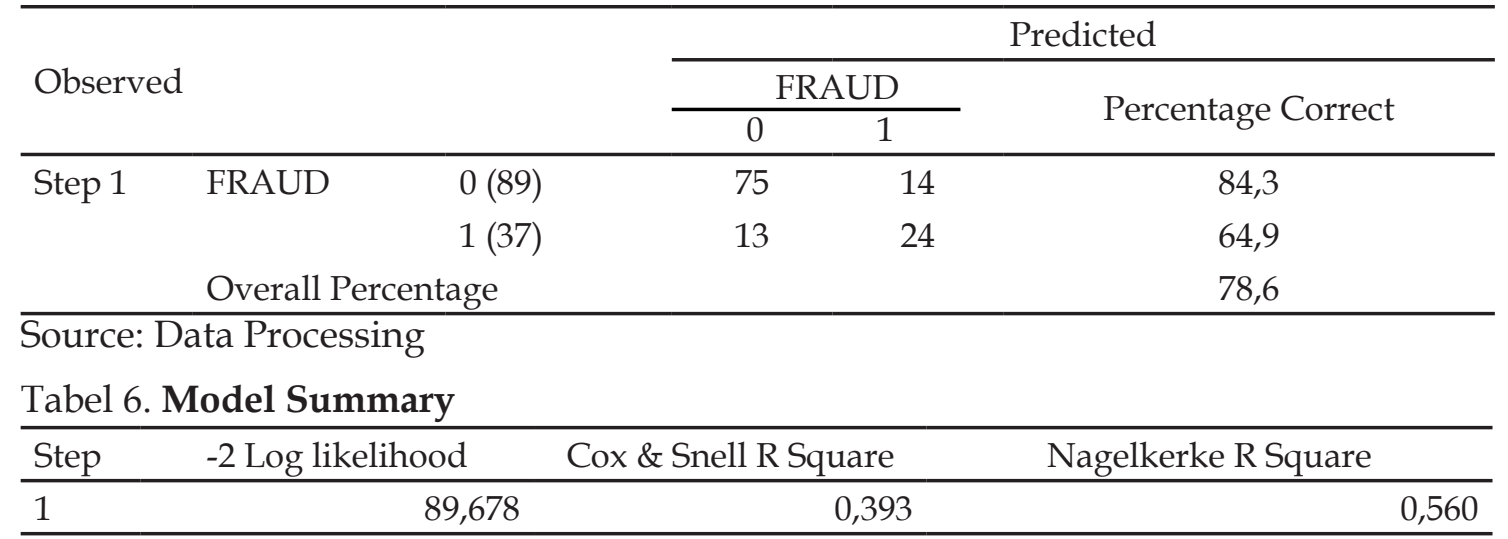

Source: Data Processing 
Tabel 4. Hosmer and Lemeshow Test

\begin{tabular}{lccc}
\hline Step & Chi-square & df & Sig. \\
\hline 1 & 13,703 & 8 & 0,090 \\
\hline \multicolumn{2}{l}{ Source: Data Processing }
\end{tabular}

Matrix Classification

Classification test is used to clarify the regression logistic model used in predicting with the observational data. Table 5 , shows that the predictions for not FFR were 89 companies, while the observations found 75 , thus the accuracy is $84,3 \%$. Otherwise companies that predicted to do FFR were 37, while the results found 24 , so the accuracy is $64,9 \%$. Or the overall classification accuracy in this study was $78,6 \%$.

\section{Coefficient Determination}

Nagelkerke R Square indicates the amount of variability of the dependent variable that can explain by the independent variables. Table 6 , shows the value of $\mathrm{R}^{2}$ is 0,56 means that the variability of the dependent variable that can be explained by the independent variable is $56 \%$, while the remaining $44 \%$ explained by other variables outside this studied model.

\section{Partial Test}

a. AGROW shows a significant value of 0,005 means H1 is accepted. This proven that the greater ratio of growth in total assets lead the probability of fraudulent financial statements. This is in line with studied from Tessa \& Harto (2016), Siddiq et al. (2017), Aprilia (2017), Septriani \& Handayani (2018).

b. BODC shows a significant value of 0,000 means $\mathrm{H} 2$ is accepted. This proven the indication that changes in directors are often filled with political content and the interests of particular parties which trigger the conflict of interest that brings out an instability condition of command and control inside, management who has capability utilised this stress period to commit fraud. This is in line with studied from Marurung \& Hardika (2015), Siddiq et al. (2017), Sasongko \& Wijayantika (2019).

c. AUDF shows a significant value of 0,034 means H3 is accepted. Audit Firms who receive high fees tend to face the complexity of conflict of interest in deliver the unqualified opinion and objective to maintain clients. Auditors are became reluctant to carry out findings, even they are collude with clients to manipulate the financial reports with large audit fees. This result streng then the studied from Bamber (2001) and Hafizi (2019).

d. EPRO shows a significant value of 0,049 means H4 is accepted. This proven the indication that e-procurement/e-tendering is able

Table 7. Wald Test

\begin{tabular}{llccccc}
\hline Wald Test & B & S.E. & Wald & Sig. & Hyphothesis \\
\hline Step 1 & AGROW & 2,288 & 0,811 & 7,950 & 0,005 & H1 accepted \\
& BODC & 0,777 & 0,188 & 17,042 & 0,000 & H2 accepted \\
& AUDF & $-0,650$ & 0,307 & 4,482 & 0,034 & H3 accepted \\
& EPRO & $-1,176$ & 0,597 & 3,880 & 0,049 & H4 accepted \\
& CHGAC & $-0,565$ & 0,276 & 4,191 & 0,041 & H5 accepted \\
& WBS & $-3,945$ & 1,406 & 7,876 & 0,005 & H6 accepted \\
& GOVSHIP & $-6,530$ & 1,632 & 16,015 & 0,000 & H7 accepted \\
& CEOEDU & $-0,486$ & 1,437 & 0,114 & 0,735 & H8 rejected \\
& CEOMIL & 0,104 & 1,231 & 0,007 & 0,933 & H9 rejected \\
& Constant & 20,540 & 7,239 & 8,006 & 0,005 & \\
\hline
\end{tabular}

Source: Data Processing 
to mitigate and prevent the collusion model in the public sector through the mechanism of procurement which is very harmful and disadvantage by increasing the price or reduce the quality of the goods/services. This is in line with studied from Jasin et al. (2007), Djojosoekarto (2008), Haryati et al. (2011). However EPRO as collusion factor in fraud hexagon is considered new in the study of FFR, this can be a reference for future works.

e. CHGAC shows a significant value of 0,041 means H5 is accepted. The high frequency of changing in audit committee might affect the company's internal control, leaving a hole that can exploit by the opportunists. Companies who commit fraud tend to do audit committee replacement, this is to reduce the possibility of detecting fraudulent financial statements as Loebbecke et al. (1989), found that 36\% of cases of fraud occurred within the first two years of the auditor's tenure. Shu (2000), obtain empirical evidence that the resignation of auditors is positively related to the possibility of litigation. And Krishnan (2005), found through his sample that companies who change its audit committee were not disclosed their internal control problems, this raise a question why they did not disclosed? A lot of studies examined change in internal audit, but exiguous in audit committee, I suggest to test this variable again on the next research.

f. WBS shows a significant value of 0,005 means H6 is accepted. Whistleblowing system empirically proven can be an important instrument in maintain workplace confideality as well as company profit and reputation. Firmswith large assets urgently require a hotline channel against fraud. This result confirm the preceding study from Naomi (2015), who conclude that the application of WBS in Telkom and Pertamina run quite well due to a decline level of fraud from 2010 to 2013, thus other research from by Agusyani et al. (2016), Pamungkas et al. (2017), Utami (2018). However WBS as an opportunity factors shall explore further for next studies.

g. GOVSHIP shows a significant value of 0,000 means H7 is accepted. A large percentage of share ownership associated the process of preparing financial reports which have possibility of discretional accrual happen, this unfold the management rationalization to carry out fraud. However, this is inline with study from Aviantara (2019), and ACFE (2017) who concluded that the climate of Indonesian government or Indonesian public sector considered high from the fraudulent activity.

h. CEOEDU shows unsignificant value of 0,735 means $\mathrm{H} 8$ is rejected. This study expects the hypothesis result that higher the level of education inline with higher awareness of anti-fraud manner, i expect the CEO become more straight and wise. But this study couldn't reinforce the arguments from Graham \& Harvey (2002), Bantel \& Jackson (1989), Benmelech \& Frydman (2015), King et al., (2016). Iargue this because fraud is ethical behavior which have big portion through informal education like home parenting, religious discourse, and public moral lectures, a huge different with performance or technical that taught from formal education, so whoever high educated people, fraudsters live in different dimension. This reasoning supported by alittle number of doctoral/PhD which is only $9.8 \%$ from the entire sample. Therefore another analysis suggest to find the appropriate company characteristics or find more appropriate research models.

i. CEOMIL shows unsignificant value of 0,933 means $\mathrm{H} 9$ is rejected. I begin with thought that CEO who are militarily affiliated have legitimacy to deliveran other fruit to the company, but does the CEO maneuver parallel with the accounting principles? Crouch (1978), 
Asia Pacific Fraud Journal, 6(1) January-June 2021: 26-42 | 37

Table 8. Omnibus Test

\begin{tabular}{llllll}
\hline \multicolumn{2}{l}{ Omnibus Test } & Chi-square & df & Sig. & Hyphothesis \\
\hline Step 1 & Step & 62,880 & 9 & 0,000 & \\
& Block & 62,880 & 9 & 0,000 & \\
& Model & 62,880 & 9 & 0,000 & H10 accepted \\
\hline
\end{tabular}

Source: Data Processing

started the discussion with military connection to lower interest rate, followed by Lennox et al. (2011), Kim \& Zhang (2016), Harymawan (2018), while Kamelia (2018), has another approach through revaluation method. But from the fraud perspective this studyis fail in provingthe military association with the FFR. This might have strong relationship with the nature of militarism itself, identic with silent operations and confideality, hence there are many barriers and high mountain to climb. This study also found that the CEO military portion is only $5.7 \%$ from the entire sample. We must find more appropriate sample to examine on wards. Although these two ego factors doesn't meet expectation in this study, it has an important notes that integrity and independency from the CEO must be sustainable and well maintained.

\section{Simultaneous Test}

Simultaneous effect shown by omnibus test, if chi-square value greater than chi-square table, there is a simultaneous effect from the independent variables to the dependent variable. Table 8 , shows the value of 62,880 higher than chi-square table 16,92 ( $\mathrm{df}=9, \mathrm{p}$ $=5 \%$ ), and significance output 0,000 means $\mathrm{H} 10$ is accepted. Hence we conclude that Financial Stability, Director Change, Audit Fee, E-Procurement, Change in Audit Committee, Whistleblowing System, Government Ownership, CEO Education, and CEO Military as the S.C.C.O.R.E model simultaneously proven can affect the FFR.

\section{CONCLUSION}

Financial Stability as the Stimulus factor which measured by asset growth affect to FFR. Director Change as the
Capability factor which measured by number of replacement affect to FFR. Audit Fee as the Collusion factor which measured by logaritma natural affect to FFR. E-Procurement as the Collusion factor which measured by existence implementation affect to FFR. Change in Audit Committee as the Opportunity factor which measured by number of replacement affect to FFR. Whistleblowing System as the Opportunity factor which measured by existence implementation affect to FFR. Government Ownership as the Rationalization factor which measured by state ownership affect to FFR. CEO Education as the Ego factor which measured by educational level could not affect to FFR. CEO Military as the Ego factor which measured by military affiliation could not affect to FFR. And Fraud Hexagon or the S.C.C.O.R.E model simultaneously affect to FFR. Implications for the auditors are to include all the tested variables in this study through the list of questionaries when performing initial meeting in order to assess the risk of fraud, even for all the stakeholders can be signalling tools to adopt a scepticism manner if any conditions encountered. And for all government companies who didn't have a whistleblowing system, strongly suggest to implement immediately, because this study streng then the importance of hotlines system as one of the most effective tools of fraud eradication. Limitations, not all state companies listed on stock exchange (IDX) inserted into this research due to difference population, there are other subsidiaries BUMN or BUMD were not included in this purposive sampling such as AGRO, ANTM, BJBR, ELSA, PGAS, PPRO, PTBA, SMBR, TINS, WSBP, WTON and so on. The minimum 
number of doctoral CEO which is 9,8\% and the military CEO is only $5,7 \%$ from the entire sample, therefore need to find the appropriate company characteristics, more precise models, and more specific sectors. Some proxies have intersect debatable characteristics according to every point of view, Director change might represent capability and opportunity, government ownership might represent rationalization and opportunity, CEO education might represent anti ego and capability, hence forthe next studies suggest to find stand alone proxies.

\section{ACKNOWLEDGEMENTS}

Endorsed by Dr. Hermiyetty, Msi., CSRA., and Prof. Dr. Haryono Umar, Msc., Ak., CA., from Trisakti University Jakarta as thesis supervisor.

\section{REFERENCES}

Abbott, L. J., Park, Y., and Parker, S. 2000. The effects of audit committee activity independence on corporate fraud. Journal of Managerial Finance, 26 (11): 55-67.

ACFE. 2020. Report to The Nations: On Occupational Fraud and Abuse. Available at https://acfe.com (accessed 5 June 2020).

ACFE Indonesia Chapter. 2017. Survai Fraud Indonesia. Available at https:// acfe-indonesia.or.id (accessed 5 June 2020).

Aghghaleh, S. F., Mohamed, Z. M., and Rahmat, M.M. 2016. Detecting Financial Statement Frauds in Malaysia: Comparing the Abilities of Beneish and Dechow Models. Asian Journal of Accounting and Governance, Vol. 7: 57-65.
Agusyani, K.S., Sujana, E., dan Wahyuni, M.A. 2016. Pengaruh Whistleblowing System dan Kompetensi Sumber Daya Manusia terhadap Pencegahan Fraud Pada Pengelolaan Keuangan Penerimaan Pendapatan Asli Daerah. Akuntansi Ganesha, Vol. 6, No. 3.

Aprilia. 2017. Analisis Pengaruh Fraud Pentagon Terhadap Kecurangan Laporan Keuangan Menggunakan Beneish Model Pada Perusahaan Yang Menerapkan Asean Corporate Governance Scorecard. Jurnal Akuntansi Riset, 9 (1): 101-132.

Aviantara, R. 2019. The BIG 4 Role in Moderating the Detection of Fraud Pentagon Against Fraudulent Financial Reports. International Journal of Sciences: Basic and Applied Research, Vol. 48, No. 4: 93-109.

Asiah, N., dan Setyorini, D. 2017. Pengaruh Bystander Effect dan Whistleblowing Terhadap Terjadinya Kecurangan Laporan Keuangan. Jurnal Nominal, Vol. VI, No. 1.

Bhagat, S., Bolton, B.J., and Subramanian, A. 2010. CEO Education, CEO Turnover, and Firm Performance. Available at SSRN: https://ssrn. com/abstract $=1670219$. (accessed 31 June 2020).

Bamber, M.R. 2001. Overcoming Your Workplace Stress: A CBT-Based Self. Routledge: 232.

Bantel, K.A., and Jackson, S.E. 1989. Top Management and Innovations in Banking: Does the composition of the top team make a difference? Strategic Management Journal, 10: 107-124. 
Beneish, M.D. 1999. The Detection of Earnings Manipulation. Financial Analysts Journal, 55 (5): 24-36.

Benmelech, E., and Frydman, C. 2015. Military CEO's. Journal of Financial Economics, Vol. 117 (1): 43-59.

Cressey, D. 1953. Other People's Money: A Study In The Social Physhology of Embezzlement. Glencoe: Free Press.

Crouch, H. 1978. The Army and Politics in Indonesia. Cornell University Press.

Davidson, R., Stewart, J.G., and Kent, P. 2005. Internal governance structure and earnings management. Accounting and Finance, Vol. 45: 241-267.

Dechow, P.M., Weili, G., Larson, C.R., and Sloan, R.G. 2011. Predicting Material Accounting Misstatements. Contemporary Accounting Research, 28: 17-82.

Djojosoekarto, A. 2008. E-Procurement di Indonesia: Pengembangan Layanan Pengadaan Barang dan Jasa Pemerintah Secara Elektronik. Jakarta: Partership Kemitraan dengan LPSE Nasional.

Ghozali, I. 2016. Aplikasi Analisis Multivariete Dengan Program IBM SPSS 23, Edisi 8. Semarang: Universitas Diponegoro.

Graham, J., and Harvey, C. 2002. How do CFO's make capital budgeting and capital structure decisions? Journal of Applied Corporate Finance, 15 (1): 8-23.

Haryati, D., Anditya, A., dan Wibowo, R.A. 2011. Pelaksanaan Pengadaan Barang/Jasa Secara Elektronik (E-Procurement) Pada Pemerintah Kota Yogyakarta. Jurnal Mimbar Hukum, Vol. 23, No. 2.
Harymawan, I. 2018. Why do firms appoint former military personnel as directors? Evidence of loan interest rate in militarily connected firms in Indonesia. Asian Review of Accounting, Vol. 26, No. 1: 2-18.

Hikmawati, P. 2017. Dugaan Suap Dalam Mendapatkan Opini WTP. Majalah Info Singkat, Vol. IX, No.11/I/ Puslit/Juni.

Jayanthi Krishnan. 2005. Audit Committee Quality and Internal Control: An Empirical Analysis. The Accounting Review, Vol. 80 (2): 649-675.

Jasin, M., Zulaiha, A.R., Rachman, E.J., dan Ariati, N. 2007. Mencegah Korupsi melalui e-Procurement. Komisi Pemberantasan Korupsi, Deputi Pencegahan, Direktorat Penelitian dan Pengembangan.

Jensen, M.C., and Meckling, W.H. 1976. Theory of the Firm: Managerial Behavior, Agency Costs and Ownership Structure. Journal of Financial Economics, Vol. 3: 305-360.

Juliana, R., dan Erlim, K.W. 2017. Pengaruh Tingkat Edukasi dan Spesialisasi Pendidikan CEOterhadap Performa Perusahaan Di Indonesia. Jurnal Manajemen Maranatha. Vol. 16, No. 2: 133-212.

Kamarudin, K.A., and Ismail, W.A.W. 2014. The Effect of Audit Committee Attributes on Fraudulent Financial Reporting. Journal of Modern Accounting and Auditing, 10 (5): 507-514.

Kamelia, A. 2018. Latar Belakang Politik, Militer, Akuntansi, Kompensasi,dan Leverage Serta Pengaruhnya Terhadap Keputusan Revaluasi Aset Tetap. Available at https:// repository.unair.ac.id (accessed 31 June 2020). 
40| Ryan Aviantara, The Association Between Fraud Hexagon and Government's Fraudulent

Kim, C.F., and Zhang, L. 2016. Corporate Political Connections and Tax Aggressiveness. Contemporary Accounting Research, Vol. 33, No. 1: 78-114.

King, T., Srivastav, A., and Williams, J. 2016. What's in an education? Implications of CEO education for bank performance. Journal of Corporate Finance, No. 44.

Klein A. 2002. Audit committee, board of director characteristics, and earnings management. Journal of Accounting and Economics, Vol. 33: 375-400.

Klein, H., and Fitzgerald, A. 2018. The Cost of Occupational Fraud - Association of Certified Fraud Examiners Survey Results. Eisneramper.

Kompas. 2020. Korupsi di Asabri Terendus, Modus Sama dengan Jiwasraya dan Tak Kalah Fantastis. Available at: https://nasional.kompas.com (accessed 5 June 2020).

Lee, G., and Fargher, N. 2012. Companies Use Whistleblowing to Detect Fraud: An Examination of Corporate Whistle-Blowing Policies. Journal Business Ethics, 114: 283-295.

Lennox, C.S., Francis, J.R., and Wang, Z. 2011. Selection Models in Accounting Research. The Accounting Review, Vol. 87, No. 2: 589-616.

Lisa A., and Robinson D. 2009. Audit Committee Characteristics and Auditor Changes. Academy of Accounting and Financial Studies Journal, Special Issue, Vol. 13, 117132.

Loebbecke, J.K., Eining, M.M.,and Willingham, J.J. 1989. Auditor's Experience with Material Irregularities: Frequency, Nature and Detectability. Auditing: A Journal of Practice and Theory, 9 (1): 1-28.
Manurung, D.T.H., dan Hardika, A.L. 2015. Analysis of Factors that Ifluence Financial Statement Fraud in the Perspective Fraud Diamod: Empirical Study on Banking Companies Listed on the Indonesia Stock Exchange. International Conference on Accounting Studies (ICAS)

Muradi. 2007. Metamorfosis Bisnis Militer: Sebaran Bisnis TNI Pasca UU TNI. Jakarta: The RIDEP Institute.

Naomi, S. 2015. Penerapan Whistleblowing System dan Dampaknya Terhadap Fraud. Available at https://digilib. unila.ac.id (accessed 31 June 2020).

OECD, 2009. Principles for Integrity in Public Procurement. Available at https://oecd.org (accessed 5June 2020).

Pamungkas, I.D., Ghozali, I., dan Achmad, T. 2017. The Effects of The Whistleblowing System on Financial Statements Fraud with Ethical Behavior as Mediator. International Journal of Civil Engineering and Technology, Vol. 8, Issue 10: 15921598.

Rahardjo, S.N., dan Sihombing, K.S. 2014. Analisis Fraud Diamond Dalam Mendeteksi Financial Statement Fraud. Diponegoro Journal of Accounting, Vol. 03, No. 02: 1-12.

Rahmat, Mohd M., Takiah M., and Norman M, 2009. Audit committee characteristics in financially distressed and non-distressed companies. Managerial Auditing Journal, Vol. 24, No. 7.

Robbins, S. P., and Judge, T. A, 2015. Organizational Behavior. $16^{\text {th }}$ ed. USA: Pearson. 
Asia Pacific Fraud Journal, 6(1) January-June 2021: 26-42 | 41

Sasongko, N., dan Wijayantika, S. F., 2019. Faktor Resiko Fraud Terhadap Pelaksanaan Fraudulent Financial Reporting Berdasarkan Pendekatan Crown's Fraud Pentagon Theory. Jurnal Riset Akuntansi dan Keuangan Indonesia, Vol. 4, No. 1.

Shu, S., 2000. Auditor Resignations: Clientele Effects and Legal Liability. Journal of Accounting and Economics, 29 (2): 173-205.

Siddiq, F. R., Achyani, F., dan Zulfikar, 2017. Fraud Pentagon dalam Mendeteksi Financial Statement Fraud. Seminar Nasional the 4th Call for Syariah Paper, 1-14.

Skousen, C. J., and Twedt, B. 2009. Fraud score analysis in emerging markets. Cross Cultural Management, Vol. 16, No. 3: 301-316.

Susmanchi, G. 2012. Internal Audit and Whistle-Blowing. Economics, Management, and Financial Markets, Vol. 7 (4): 415-421.

Tessa, C.G., dan Harto, P. 2016. Fraudulent Financial Reporting: Pengujian Teori Fraud Pentagon Pada Sektor Keuangan dan Perbankan di Indonesia. Simposium Nasional Akuntansi XIX, Lampung: 1-21.
Utami, L. 2018. Pengaruh Audit Internal dan Whistleblowing System terhadap Pengungkapan Kasus Kecurangan Perusahaan Sektor Jasa di BEI. Jurnal Studi Akuntansi dan Keuangan, Vol. 1(2): 77-90.

Vousinas, G. L. 2019. Advancing theory of fraud: the S.C.O.R.E. model. Journal of Financial Crime, Vol. 26, Issue 1: 372-381.

Wibowo, R. A. 2015. Preventing Corruption in Public Procurement: What has been done and what should be done? Corruption Eradication Commission (KPK). Jurnal Integritas, Vol. 1, No. 1: 37-60.

Wolfe, D.T., and Hermanson, D. R. 2004. The Fraud Diamond: Considering the Four Elements of Fraud. The CPA Journal, 74(12): 38-42. 
42| Ryan Aviantara, The Association Between Fraud Hexagon and Government's Fraudulent

Appendix 1.

\begin{tabular}{|c|c|c|}
\hline Variable & Abbreviation & Calculation \\
\hline \multirow[t]{5}{*}{$\begin{array}{l}\text { RSST } \\
\text { accruals }\end{array}$} & rsst_ace & $\begin{array}{l}(\Delta \mathrm{WC}+\Delta \mathrm{NCO}+\Delta \mathrm{FIN}) / \\
\text { Average total assets }\end{array}$ \\
\hline & & Where: \\
\hline & & $\begin{array}{l}\text { WC }=\text { [Current assets - Cash and } \\
\text { short-term investments] - [Current } \\
\text { liabilities - Debt in current } \\
\text { liabilities] }\end{array}$ \\
\hline & & $\begin{array}{l}\text { NCO }=\text { [Total assets - Current } \\
\text { assets - Investments and } \\
\text { advances] - [Total liabilities - } \\
\text { Current liabilities - Long-term } \\
\text { debt] }\end{array}$ \\
\hline & & $\begin{array}{l}\text { FIN }=\text { [Short-term } \\
\text { investments + Long-term } \\
\text { investments] - [Long-term } \\
\text { debt + debt in current } \\
\text { liabilities + Preferred stock] }\end{array}$ \\
\hline $\begin{array}{l}\text { Change in } \\
\text { receivables }\end{array}$ & ch_rec & $\begin{array}{l}\Delta \text { Accounts receivable/Average total } \\
\text { assets }\end{array}$ \\
\hline $\begin{array}{l}\text { Change in } \\
\text { inventory }\end{array}$ & ch_inv & $\Delta$ Inventory/Average total assets \\
\hline $\begin{array}{l}\text { Percentage of } \\
\text { soft assets }\end{array}$ & soft_assets & $\begin{array}{l}\text { (Total assets - PP\&E - Cash and } \\
\text { cash equivalent)/Total assets }\end{array}$ \\
\hline $\begin{array}{l}\text { Change in } \\
\text { cash sales }\end{array}$ & ch_cs & [Sales $-\Delta$ Accounts receivable] \\
\hline $\begin{array}{l}\text { Change in } \\
\text { return on } \\
\text { assets }\end{array}$ & ch_roa & $\begin{array}{l}\text { [Eamings } / \text { Average total assets }]- \\
{\left[\text { Earnings }_{\mathrm{t}}-{ }_{1} / \text { Average total }\right.} \\
\left.\text { assets }_{\mathrm{t}}-1\right]\end{array}$ \\
\hline $\begin{array}{l}\text { Actual } \\
\text { issuance }\end{array}$ & issue & $\begin{array}{l}\text { An indicator variable coded } 1 \text { if the } \\
\text { firm issued securities during year } t \text {. }\end{array}$ \\
\hline
\end{tabular}

